Збірник наукових прачь Державного науково-дослідного інституту випробувань і сертифікачії озброєння та військової техніки. 2019. Вип. № 2

ISSN 2706-7386

УДК 629.3.018.4

DOI: $10.37701 /$ dndivsovt.2.2019.21

Чуприна В.М. Державний науково-дослідний інститут випробувань $i$ сертифікації озброєння та військової техніки

\title{
МОДЕЛЮВАННЯ КАПСУЛИ БРОНЕАВТОМОБІЛЯ ДЛЯ ОЦІНКИ МІЦНОСТІ ПРИ ВИПРОБУВАННЯХ
}

Розглянута актуальна проблема визначення $i$ оцінки характеристик міциноті спеціальних бронеавтомобілів при їх перекиданні або перевертанні з метою збереження життєвого простору $і$ життя людей. Розроблена методика імітаиійного моделювання міиності капсули бронеавтомобіля за методом скінчених елементів. Виконаний аналіз напружено-деформованого стану капсули бронеавтомобіля під дією різних видів навантажень. Надані рекомендаџії щ̧одо оцінки міцності капсули та визначення коефіцієнтів запасу міцності конструкиіï.

Ключові слова: бронеавтомобіль, перекидання, капсула, міиність, життєвий простір, моделювання.

Вступ. Випробування військової техніки і техніки подвійного призначення $\epsilon$ головним фактором забезпечення силових структур держави якісною спецтехнікою, зокрема спеціальними бронеавтомобілями. Метою проведення випробувань є визначення та оцінка бойових, технічних і експлуатаційних характеристик, представлених на випробування, зразків техніки.

Постановка проблеми. Бронеавтомобілі призначені для захищеного перевезення особового складу, зокрема i в районах проведення бойових дій. Одним із важливих показників бронеавтомобіля є міцність його капсули, в якій знаходяться люди (екіпаж i пасажири). Капсула повинна забезпечити не тільки балістичний захист особового складу від стрілецької зброї та інших видів уражень, але й забезпечити збереження життєвого простору для людей при перекиданні чи перевертанні автомобіля.

Оцінювати міцність корпусу автомобіля під час випробувань можна як експериментальним, так і розрахунковим шляхом. При цьому розрахунковий шлях є більш прийнятним, тому що він дозволяє суттєво скоротити терміни випробувань та зменшити загальні витрати на випробування. Крім того сам автомобіль залишається неушкодженим.

Сучасним методом оцінювання показників і характеристик об’єкта випробувань є моделювання [1]. Моделювання виконується на комп'ютері у віртуальному середовищі шляхом складання моделі, як аналога об'єкта, та іiі вивчення. При цьому можна задавати різноманітні моделі впливу на об’єкт (іноді навіть за межами реальних можливостей), а також значно розширювати кількість параметрів моделювання.

Математичне та імітаційне моделювання об’єктів $є$ важливою складовою розробки спецтехніки, яке суттєво розширює можливості проектування, виробництва і випробування принципово нової техніки, створеної на основі сучасних технологій.

Розглянемо можливості і методику застосування імітаційного моделювання для оцінки міцності корпусу бронеавтомобіля на випробуваннях.

Мета роботи - розробка методики визначення та оцінки характеристик міцності бронекапсули спеціальних автомобілів при їх перекиданні.

Відпрацювання методики будемо виконувати на прикладі багатоцільового тактичного автомобіля (БТА) “КОЗАК” (рис.1), призначеного для перевезення особового складу. БТА має броньовану капсулу для захисту екіпажу і особового складу від стрілецької зброї та інших видів уражень. Капсула повинна бути достатньо міцною, щоб забезпечити збереження необхідного життєвого простору для людей при перекиданні автомобіля. 
Капсула автомобіля (рис.2) - це складна механічна конструкція, яка містить багато різних елементів (вузлів і деталей), поєднаних між собою роз'ємними і нероз'ємними з'єднаннями.

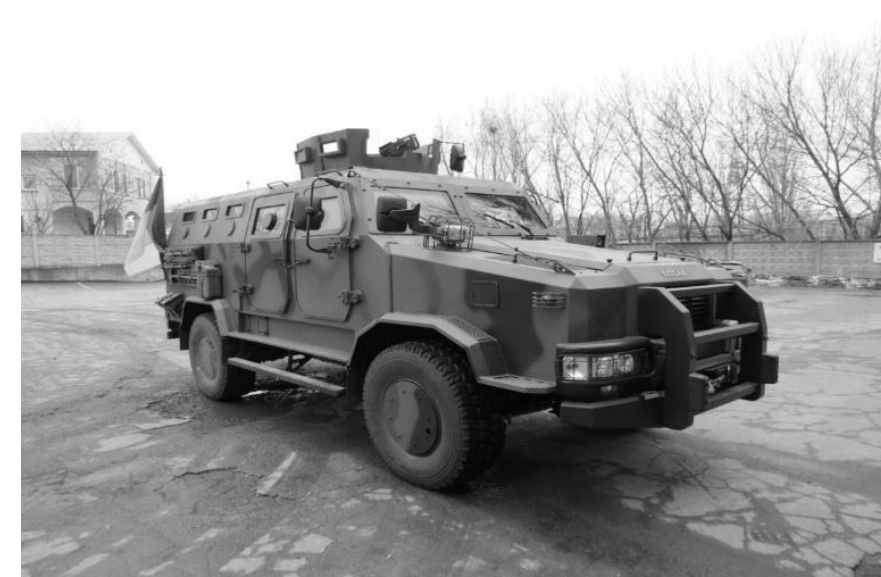

Рис.1. Загальний вид БТА “КОЗАК”

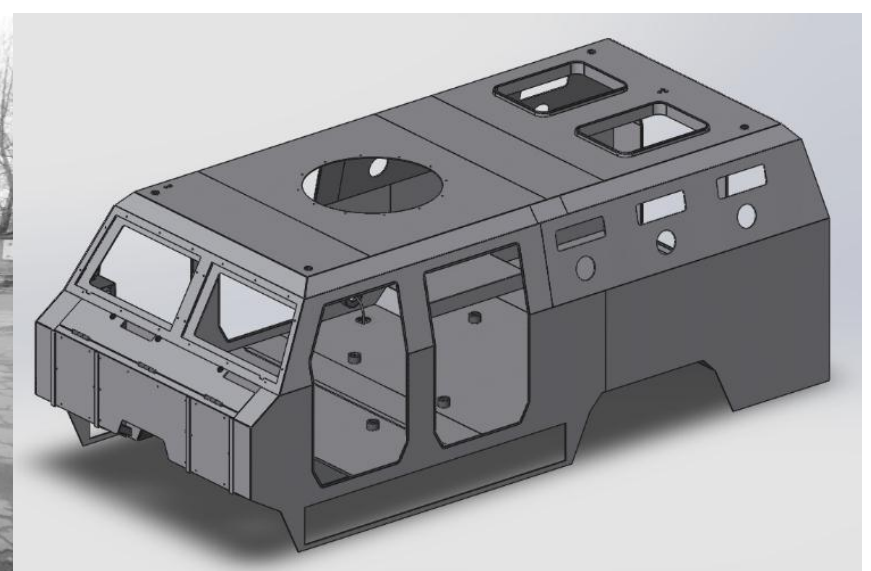

Рис.2. Капсула БТА “КОЗАК”

Конструкція капсули БТА складається 3 базового зварного каркасу із труб квадратного профілю 50х50x4 (сталь 3), зовнішньої і внутрішньої обшивок, зварених за допомогою зварювального дроту марки Св-08Х20Р9Г7Т з листів спеціальної бронесталі марки Miilux protection 500. Між зовнішньою і внутрішньою обшивками розміщено шар зі спеціального скловолокна. Основну міць конструкції, яка сприймає силове навантаження при перекиданні автомобіля, складає каркас i зовнішня обшивка. Тому, при силових розрахунках обмежимось лише 3D-моделлю силової частини капсули.

При аналізі міцності капсули необхідно розглядати конструкцію як складну пружну систему, для аналізу якої варто застосовувати системний підхід, що базується на методології аналізу іiі частин 3 урахуванням цілісності всієї системи. При цьому доцільно використовувати декомпозиційні методи аналізу структури складних систем і досліджувати пружну систему по частинах (елементах).

Найбільш розповсюдженим на сьогодні декомпозиційним методом аналізу складних конструкцій машин є метод скінчених елементів (МСЕ). Імітаційне моделювання за МСЕ доцільно виконувати в програмі SolidWorks Simulation [2-5], яка дозволяє не тільки проектувати, але й розраховувати складні машинобудівні конструкції 3 використанням різних матеріалів і видів 3'єднань між елементами.

Розрахунок капсули БТА “КОЗАК” на міцність [6] проводиться з урахуванням відомої методології імітаційного моделювання випробувань на відповідність Правилам №66 ЄЕК OОН (ДСТУ UN/ECE R 66-00:2002) [7], що прийняті до застосування в Україні (Правила ЄЕК ООН №№ 1-4, 6-14, 16-20, 23-30, 34-41, 43, 46-52, 54-63, 66, 67, 69-83, 85, 86, 90, 92, 93, 96, 103-105. Наказ Мінтрансу України від 04.06.2002 № 361) [8]. Ці правила призначені для забезпечення необхідної міцності конструкції та збереження життєвого простору для людей при перекиданні автомобіля.

\section{Виклад основного матеріалу.}

При моделюванні міцності конструкції розглядається напружено-деформований стан капсули автомобіля під дією статичних і динамічних навантажень. Навантаження автомобіля при його перекиданні складається з сил тяжіння від власної ваги машини та додаткового вантажу і людей (статична складова), а також від сил інерції маси автомобіля (динамічна складова).

При перекиданні автомобіля навантаження від дії зовнішніх сил може бути прикладене до будь-якої частини капсули, що апріорі не визначено. Однак, перекидання автомобіля в повздовжньому до руху напрямку мало ймовірно. Тобто, практика доводить, що 
в більшості випадків перекидання стається на бік (на правий чи лівий борт), на ребро корпусу або відбувається перевертання автомобіля на дах.

У відповідності до Правил №66 СЕК ООН величина вертикального переміщення $\Delta h$ центру ваги при перекиданні може визначатися за допомогою графічного методу (рис.3).

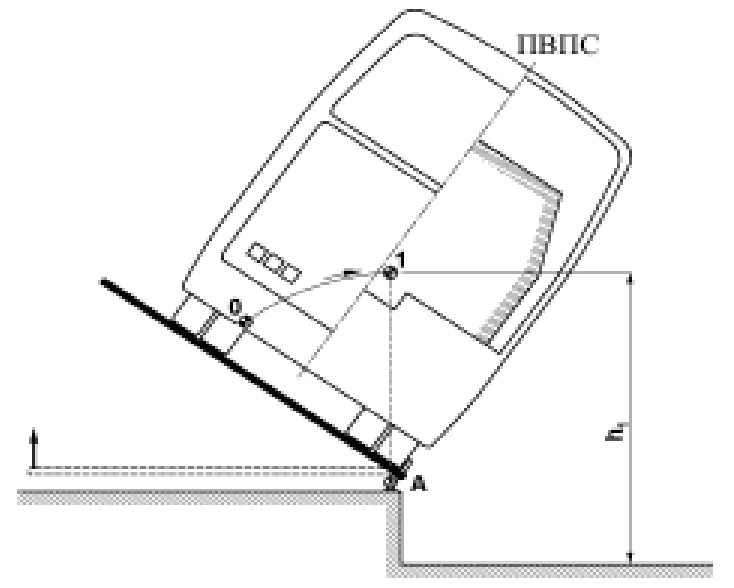

$a$

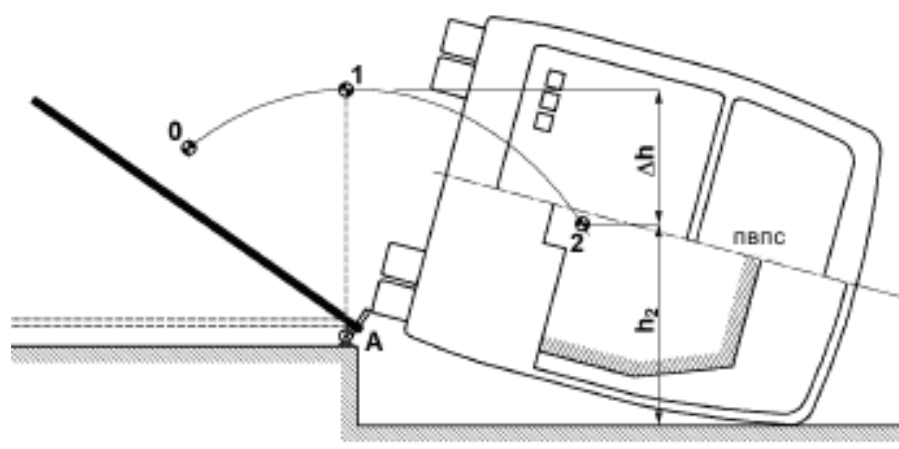

$\sigma$

Рис.3. До визначення величини вертикального переміщення центру ваги $\Delta h$

За кресленнями поперечного перерізу транспортного засобу у відповідному масштабі визначається первісна висота $\boldsymbol{h}_{1}$ центру ваги (рис.3-а) над нижньою площиною кювету, коли транспортний засіб знаходиться в стані нестійкої рівноваги на платформі для перекидання.

Відповідно до припущення про те, що поперечний переріз транспортного засобу обертається навколо краю колісних опор (точка А), на кресленні поперечного перерізу транспортного засобу нижня обв'язка торкається нижньої площини кювету (рис.3-б). В цьому положенні визначається висота $h_{2}$ центру ваги по відношенню до нижньої площини кювету. Величина вертикального переміщення центру ваги $\Delta h$ визначається як $\Delta h=h_{1}-h_{2}$, причому величина $\Delta h$ залежить не тільки від висоти центра ваги автомобіля, але і від глибини кювету. Тому навантаження на конструкцію може припадати на бік, на ребро і на дах автомобіля (рис.4).
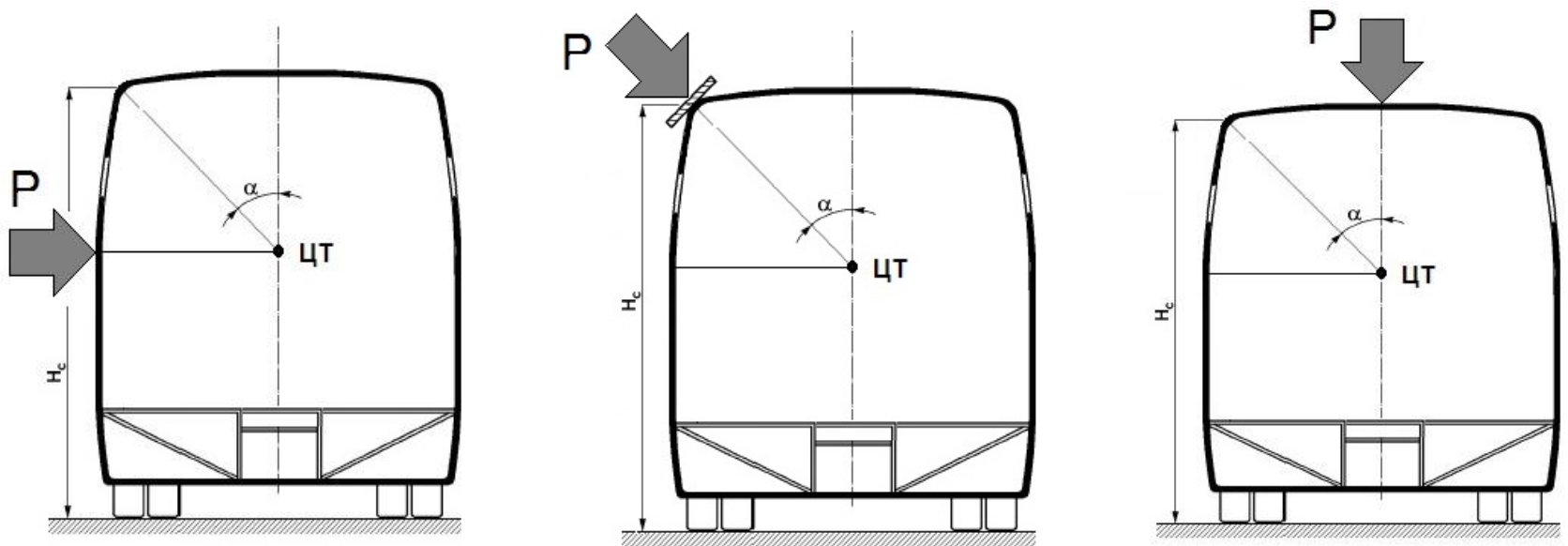

Рис.4. Варіанти прикладення навантаження на капсулу автомобіля 
При прикладенні навантаження на ребро капсули для визначення кута між жорсткою підставою і поздовжньою вертикальною серединною площиною автомобіля $a$ можна користуватися таким співвідношенням:

$$
a=90-\arcsin \left(800 / H_{c}\right),
$$

де $H_{c}$ - висота автомобіля.

Плоска підстава моделюється скінченими елементами (CE), для яких використовується модель абсолютно жорсткого і міцного матеріалу.

Існують наступні два види характеристик при перекиданні автомобіля: статичні і динамічні. Статичні визначаються тільки від дії сили власної ваги автомобіля (при максимальному його завантаженні). Динамічні характеристики визначаються при врахуванні сили удару, яка виникає за рахунок обертання корпусу автомобіля зі швидкістю $\omega_{0}$.

Для визначення кутової швидкості корпусу автомобіля в момент удару рекомендується використовувати наступне співвідношення:

$$
\omega_{0}=\sqrt{2} M_{a} \cdot g \cdot \Delta h / J_{u . m .}+M_{a} \cdot d^{2},
$$

де $M_{a}$ - маса автомобіля;

$J_{\text {u.m. }}$ - момент інерції автомобіля щодо поздовжньої осі, що проходить через центр ваги;

$\Delta h$ - різниця між вертикальною координатою центру ваги між моментом втрати рівноваги і моментом дотику до жорсткої поверхні;

$g$ - прискорення вільного падіння;

$d$ - відстань між краєм борта поворотної платформи і центром ваги автомобіля;

$\omega_{0}$ - кутова швидкість поворотної платформи в момент втрати автомобілем рівноваги.

Динамічні характеристики можуть визначатися або випробуванням на динамічний вплив, або використанням динамічного коефіцієнта $K_{\partial}$ для перетворення статичних характеристик. Правилами №66 СЕК ООН (додаток 8-1) визначено, що у разі застосування сталевих елементів конструкції може використовуватися динамічний коефіцієнт $K_{\partial}=1,2$ (без проведення лабораторних випробувань).

Тоді, для статичних розрахунків сила навантаження дорівнює силі ваги автомобіля і складає $\mathrm{P}_{\mathrm{c}}=147000 \mathrm{H}$, а для динамічних $-\mathrm{P}_{д}=176400 \mathrm{H}$.

Таким чином, для перевірки міцності капсули БТА “КОЗАК" за квазістатичним розрахунком (статичним, але 3 урахуванням динаміки удару) прийняте максимальне навантаження $176400 \mathrm{H}$.

Закріплення капсули до шасі автомобіля виконано за допомогою 14 втулок. Припускаємо, що при перекиданні автомобіля вони не зміщуються відносно шасі. Тому, у розрахункової моделі граничні умови закріплення капсули прийняті шляхом фіксації конструкції в 14 базових точках на полу капсули (рис.5-a). 


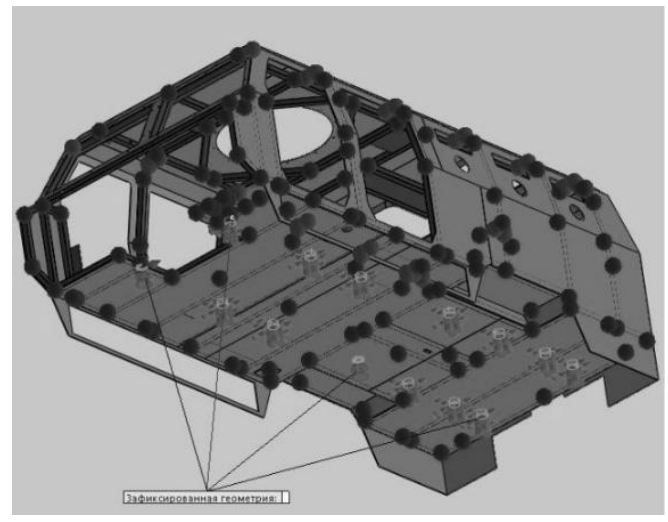

$a$

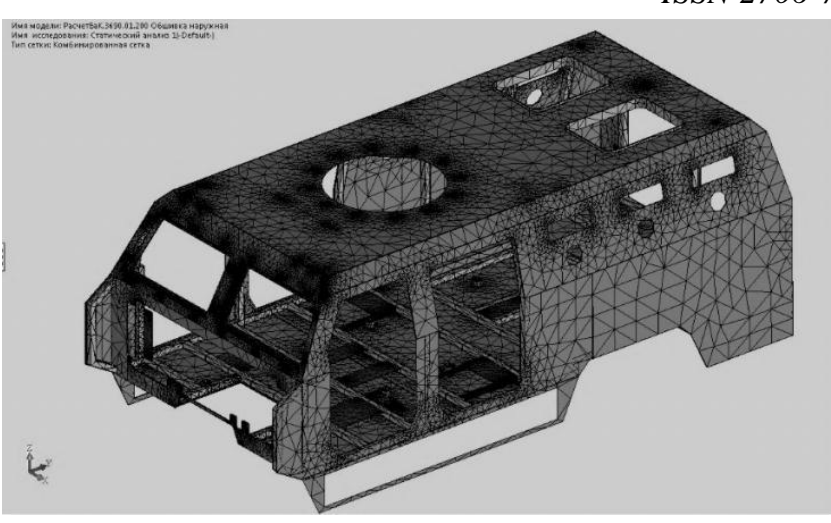

$\sigma$

Рис.5. Схема закріплення капсули (а) та її скінчено-елементна мережа (б)

Конструкція корпусу капсули містить як великі за розмірами елементи, так і дрібні, а також $є$ багато деталей з великою кількістю отворів різних розмірів, радіусів і закруглень. Для побудови скінчено-елементної мережі складної збиральної моделі доцільно використовувати комбіновану мережу 3 тетраїдальних скінчених елементів 3 розмірами, адаптованими до розмірів елементу. Це дозволяє більш точно описати властивості конструкцій з різнорідними за розмірами елементами.

Загальний вид автоматично сформованої скінчено-елементної мережі капсули, яка містить 34182 вузла і 111052 скінчених елемента, показаний на рис.5-б. Результати розрахунків корпусу капсули представляються у вигляді розподілених кольорових полів механічних напружень в матеріалі і полів деформацій конструкції.

На рис.6 показано моделювання напружено-деформованого стану корпусу (карти напружень) для різних варіантів розрахункових навантажень. У результаті проведених розрахунків визначені зони підвищених напружень корпусу (небезпечні зони).

В особливо критичних зонах конструкції виконано зондування (рис.6-г) для встановлення максимальних точкових напружень, які зведені в таблицю 1.

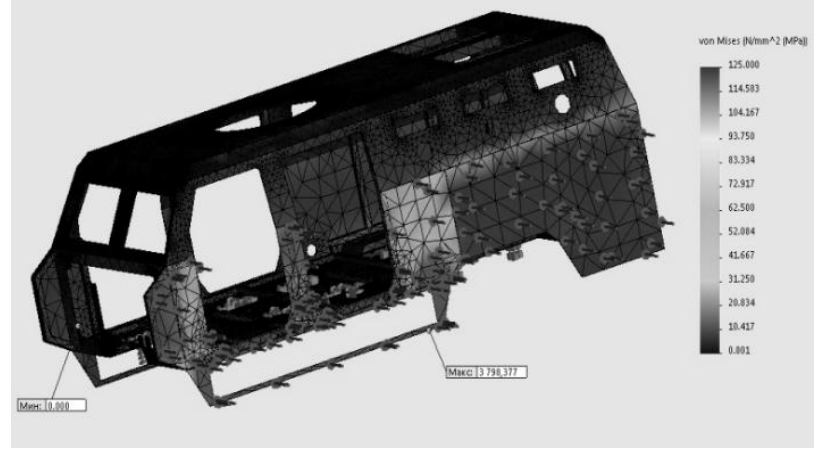

$a$

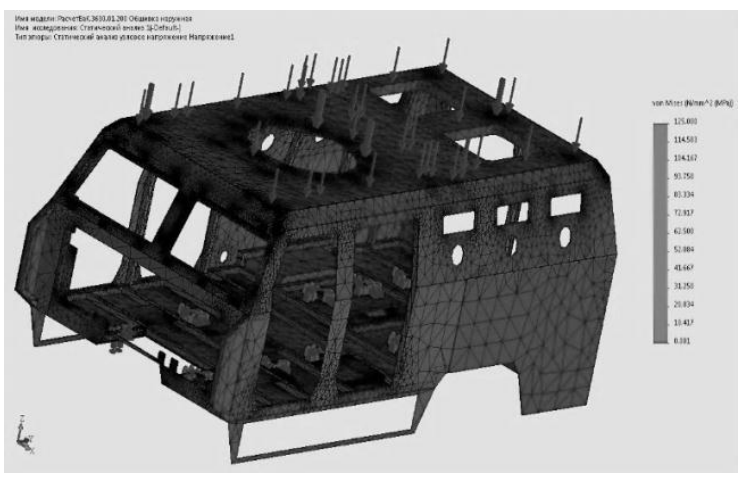

B

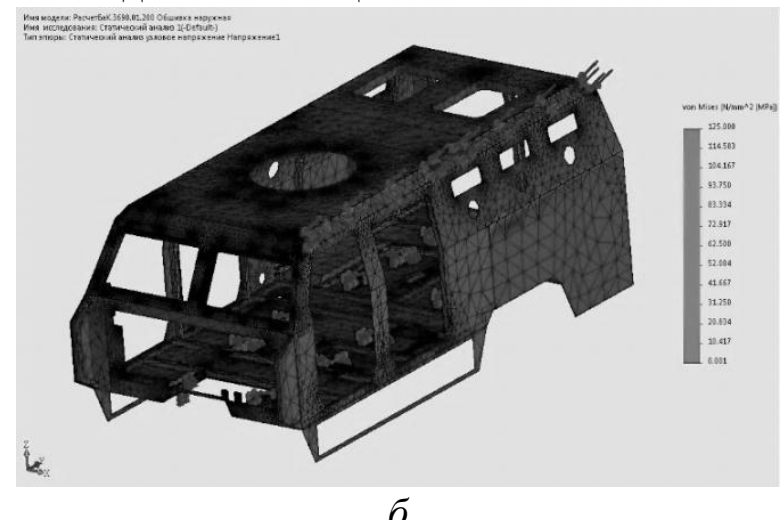

$\sigma$

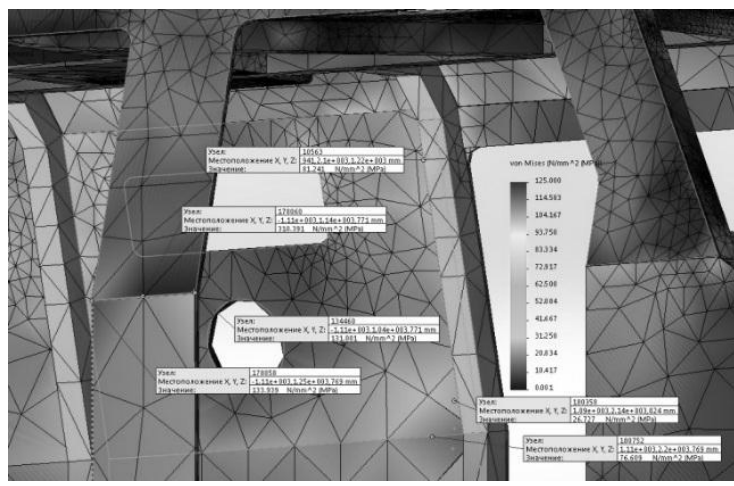

2

Рис.6. Варіанти моделювання напружено-деформованого стану капсули (а-в) та зондування величин напружень в критичних точках (г) 
Збірник наукових прачь Державного науково-дослідного інституту випробувань і сертифікачії озброєння та військової техніки. 2019. Вип. № 2

ISSN 2706-7386

Таблиця 1

Максимальні механічні напруження в матеріалах корпусу капсули

\begin{tabular}{|c|l|c|c|c|}
\hline \multirow{2}{*}{$\begin{array}{c}\text { № } \\
\text { 3.П. }\end{array}$} & \multirow{2}{*}{$\begin{array}{c}\text { Вид навантаження } \\
\text { капсули }\end{array}$} & $\begin{array}{c}\text { Сталь 3 } \\
\left(\left[\sigma_{\mathrm{B}}\right]=380\right)\end{array}$ & $\begin{array}{c}\text { Miilux Protection 500 } \\
\left(\left[\sigma_{\mathrm{B}}\right]=1600\right)\end{array}$ & $\begin{array}{c}\text { Св-08Х20Р9Г7Т) } \\
\left(\left[\sigma_{\mathrm{B}}\right]=620\right)\end{array}$ \\
\hline 1 & На бік (борт) & 34 & 106 & 89 \\
\hline 2 & На ребро & 154 & 189 & 136 \\
\hline 3 & На дах & 177 & 310 & 153 \\
\hline
\end{tabular}

Як видно з таблиці, найменший допустимий поріг міцності має сталь 3, але і для неї необідні умови міцності виконуються

$$
\sigma_{B}=177 M \Pi a<\left[\sigma_{B}\right]=380 M \Pi a .
$$

В результаті аналізу напружено-деформованого стану капсули автомобіля під дією статичних і динамічних навантажень встановлено, що максимальні напруження для усіх матеріалів не перевищують допустимі значення. Тому необхідні умови міцності капсули при перекиданні автомобіля виконуються. При цьому мінімальний коефіцієнт запасу міцності корпусу капсули (в матеріалі зварних швів) становить

$$
K_{3}=\frac{\left[\sigma_{B}\right]}{\sigma_{B}}=\frac{620}{153}=4,052287 \approx 4,05 .
$$

3 усіх матеріалів найменший запас міцності мають елементи конструкції зі сталі 3 (каркас капсули). Однак, при цьому максимальні напруження не перевищують навіть допустимих напружень плинності (195-235МПа)

$$
\sigma=177 M \Pi a<\left[\sigma_{T}\right]=195 M \Pi a .
$$

Тобто, деформації даної конструкції відбуваються практично в межах пружних деформацій матеріалу.

На рис.7 зображені форми деформацій корпусу капсули при різних варіантах навантажень (в збільшеному в 100 разів масштабі).
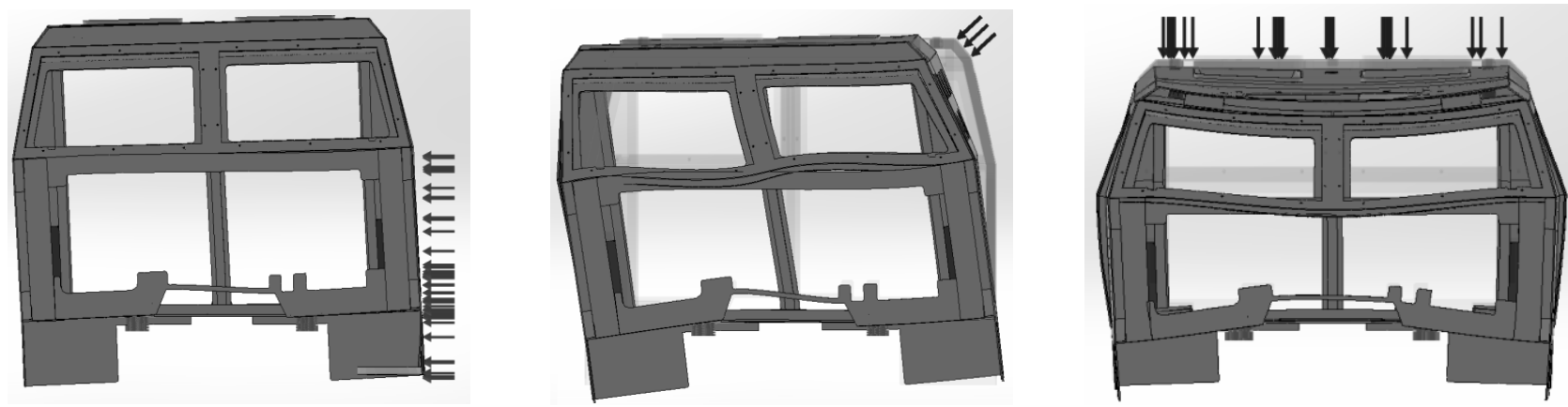

Рис.7. Форми деформації корпусу капсули при різних видах навантажень

При цьому величини розрахованих деформацій обшивки капсули $\epsilon$ незначними, їх величини не перевищують 2-3 мм при різних видах навантажень. Тому, зміни обсягу життєвого простору капсули при перекиданні БТА практично не відбуваються. Таким чином, норми Правил №66 ЄЕК ООН для даного автомобіля повністю виконуються.

Аналіз результатів моделювання і проведених розрахунків показав, що для виконання норм Правил №66 ЄЕК ООН при перекиданні бронеавтомобілів необхідно забезпечувати мінімальний коефіцієнт запасу міцності корпусу капсули $K_{3} \geq 2$.

Проведені в подальшому експериментальні випробування БТА “КОЗАК”, які містили ходові, балістичні випробування, а також підривання конструкції, підтвердили достатню міцність капсули бронеавтомобіля. 


\section{Висновки}

1. Розроблена методика імітаційного моделювання для визначення та оцінки характеристик міцності капсули спеціальних бронеавтомобілів при їх перекиданні (перевертанні) враховує усі вимоги і норми Правил №66 СЕК ООН до транспортних засобів для перевезення людей щодо міцності їх силової структури.

2. Моделювання міцності бронекапсули автомобіля доцільно проводити за методом скінчених елементів в програмі SolidWorks Simulation, яка дозволяє розраховувати складальні конструкції машин з різними матеріалами деталей.

3. Для забезпечення необхідної міцності корпусу капсули бронеавтомобіля i збереження життєвого простору для людей при перекиданні автомобіля рекомендується приймати коефіцієнт запасу міцності конструкції не менше двох одиниць.

\section{СПИСОК ЛІТЕРАТУРИ}

1. Dmytriyev V.A. Modern Methods of Modelling in Testing and Sertification of Special Technique. / V.A. Dmytriyev, V.M. Chupryna, E.K. Chimbanga // Математичне та імітаційне моделювання систем. Матеріали ХІІІ Міжнародної науково-практичної конференції "МОДС 2018”, 25- 29 червня 2018 року, Україна, м. Київ - с. Жукін. - Чернігів: ЧНТУ, 2018. - C. 376-378.

2. Алямовский A.A. SolidWorks 2007/2008. Компьютерное моделирование в инженерной практике. / А.А. Алямовский, А.А. Собачкин, Е.В. Одинцов, А.И. Харитонович, Н.Б. Пономарев. - СПб.: БХВ-Петербург, 2008. - 1040 с.

3. Алямовский A.A. COSMOSWorks. Основы расчета конструкций на прочность в среде SolidWorks / А.А.Алямовский. - Москва: ДМК Пресс, 2010. - 784 с.

4. Алямовский A.A. SolidWorks Simulation. Как решать практические задачи. / А.А. Алямовский - СПб.: БХВ-Петербург, 2012. - 448 с.

5. Алямовский А.А. Инженерные расчеты в SolidWorks Simulation. / А.А. Алямовский. - М.: ДМК Пресс, 2010. - 464 с.

6. Чуприна В.М. Перевірочний розрахунок на міцність капсули багатоцільового тактичного автомобіля “Козак-2”: збірник тез. / В.М. Чуприна, О.Ю. Борщан // Збірник тез 16-ї науково-технічної конференції “Створення та модернізація озброєння і військової техніки в сучасних умовах". - Чернігів: ДНВЦ, 2016 - С.250-252.

7. Сдині технічні приписи щодо офіційного затвердження великогабаритних пасажирських дорожніх транспортних засобів стосовно міцності верхньої частини їхньої конструкції (Правила ЕЭК ООН № 66-00:1987, DT): ДСТУ UN/ECE R 66-00:2002. / База нормативних документів. - Режим доступу: http://csm.kiev.ua/nd/nd.php?b=1\&z=87. - (Державний стандарт України).

8. Сертифікація транспортних засобів, їхніх складових (запасних) частин та обладнання. [Електронний ресурс]. / Міністерство інфраструктури України. - Режим доступу: https://mtu.gov.ua/content/sertifikaciya-transportnih-zasobiv-ihnih-skladovih-zapasnih-chastin-taobladnannya.html?.

\section{Чуприна Володимир Михайлович}

доктор технічних наук, доцент, провідний науковий співробітник Державного науководослідного інституту випробувань i сертифікації озброєння та військової техніки, Чернігів, Україна https://orcid.org/0000-0003-4886-090X +38068-131-66-06

\section{Volodymyr Chupryna}

Doctor of Technical Sciences, Associate Professor, Lead Researcher of State Scientific Research Institute of Armament and Military Equipment Testing and Certification, Chernihiv, Ukraine https://orcid.org/0000-0003-4886-090X +38068-131-66-06 


\section{SIMULATION OF THE ARMOR VEHICLE CAPSULE FOR TESTING OF STRENGTH}

\section{Chupryna}

The actual problem of determining the strength characteristics of the capsule of special armored vehicles intended for the carriage of personnel is considered.

In order to assess the strength of the capsule and the amount of final living space for people in case of turning over of the vehicle, a method of simulating the capsule strength of a special armored vehicle is proposed.

Using the example of a multipurpose tactical car, a spatial model of the prefabricated armored capsule body structure was developed. With this model, the necessary calculations and simulating modeling of the vehicle's strength were performed. The finite element method was applied to analyze the stress-strain state of the armored vehicle capsule under the force of static and dynamic loads.

The strength of the structure was evaluated and the maximum deformations of the capsule were determined. Different variants of the probable direction of application of loads on the structure, in particular the loading on the side, on the edge and on the roof of the capsule, are simulated.

The presented method of simulation mathematical modeling allows to evaluate the strength of the capsule of the armored vehicles under the test without damage and destruction of the prototype.

Recommendations have been given to calculate the strength ratios of the capsule body structures and to ensure their minimum values.

The materials presented are of practical importance for armored vehicles developers, as well as for conducting armored vehicle testing and providing reliable assessment of the strength test results.

Keywords: armored vehicle, turning over, capsule, strength, living space, modeling. 